\title{
FAKTOR YANG BERHUBUNGAN DENGAN PEMILIHAN KONTRASEPSI TUBEKTOMI WANITA USIA SUBUR
}

\author{
Istri Utami ${ }^{1}$, Efi Trimuryani ${ }^{2}$ \\ Universitas 'Aisyiyah Yogyakarta ${ }^{1,2}$ \\ istriutami@ unisayogya.ac.id ${ }^{1}$
}

\begin{abstract}
ABSTRAK
Tujuan dari penelitian ini adalah untuk mengetahui faktor yang berhubungan dengan pemilihan kontrasepsi tubektomi pada wanita usia subur. Jenis penelitian ini yaitu survei analitik dengan pendekatan cross sectional. Hasil penelitian pada 72 responden wanita usia subur menunjukkan faktor yang terbukti berhubungan dengan pemilihan alat kontrasepsi tubektomi adalah Paritas $(\mathrm{p}=0,021)$. Sedangkan faktor yang tidak berhubungan adalah Umur $(\mathrm{p}=0,732)$, Pendidikan $(\mathrm{p}=0,896)$, dan Pengetahuan $(\mathrm{p}=$ 0,086). Simpulan, faktor yang terbukti berhubungan dengan pemilihan kontrasepsi tubektomi adalah paritas. Sedangkan faktor yang tidak berhubungan adalah umur, pendidikan, dan pengetahuan.
\end{abstract}

Kata Kunci : Kontrasepsi, Tubektomi, Wanita Usia Subur

\section{ABSTRACT}

The purpose of this study was to determine the factors associated with the selection of tubectomy contraception in women of childbearing age. The type of this research is an analytic survey with a cross-sectional approach. The results of the study of 72 female respondents of childbearing age showed that the factor that was proven to be related to the choice of tubectomy contraception was Parity $(p=0.021)$. While the unrelated factors are Age $(p=0.732)$, Education $(p=0.896)$, and Knowledge $(p=0.086)$. In conclusion, the factor that has been proving to be related to the choice of tubectomy contraception is parity, whereas unrelated factors are age, education, and knowledge.

Keywords: Contraception, Tubectomy, Fertile Age Women

\section{PENDAHULUAN}

KB merupakan suatu upaya dalam pencapaian target SDG's tahun 2030 dan secara demografi peran $\mathrm{KB}$ adalah untuk mengendalikan laju pertumbuhan penduduk. KB sebagai salah satu dari 5 pilar Safe Motherhood, dalam rangka strategi menurunkan angka kematian dan kesakitan Ibu (Indraswari, Yuhan, 2017).

Penelitian yang pernah dilakukan Siregar (2018) hasil penelitian menunjukkan bahwa pengetahuan, persepsi, petugas kesehatan dan sikap memiliki hubungan dan pengaruh terhadap penggunaan kontrasepsi tubektomi. Penelitian yang dilakukan Septiwiyarsi (2017) dengan hasil ada hubungan antara umur, paritas, dukungan suami, paparan informasi dan pengetahuan dengan pemilihan Kontrasepsi MOW di RS Muhammadiyah Palembang tahun 2016. 
Penelitian Pratiwi, Sariyati (2016) dengan jenis penelitian tersebut menggunakan penelitian observasional dengan rancangan desain cross sectional. Hasil penelitian responden yaitu tidak ada hubungan antara agama dengan keikutsertaan Keluarga Berencana. Tidak ada hubungan antara keyakinan dengan keikutsertaan Keluarga Berencana. Tidak ada hubungan antara agama dengan pemilihan jenis alat kontrasepsi. Ada hubungan antara keyakinan dengan pemilihan jenis alat kontrasepsi. Penelitian ini menggunakan teknik accidental sampling.

Indonesia yang merupakan negara berkembang dengan jumlah penduduk sebanyak (3.44\%) dari total penduduk dunia, terus mengalami peningkatan dari tahun 2013-2017. Pada tahun 2013-2014 pertumbuhan penduduk meningkat dari 3,65 juta per tahun menjadi 3,70 juta per tahun. Sedangkan dari tahun 2014-2017 mulai mengalami penurunan yaitu $\pm 261,89$ juta. Hal ini dipengaruhi oleh Total Fertility Rate (TFR) atau Total angka kelahiran penduduk yang bersifat menambah jumlah penduduk (Kementrian RI, 2017).

Berdasarkan hasil SDKI 2017 sejak 10 tahun terkahir, TFR di Indonesia telah mengalami penurunan 2007 (2,6), 2012 (2,6) dan 2017(2,4), akan tetapi angka ini masih tergolong tinggi yaitu sebesar 2,4 tahun 2017. Angka pencapaian ini belum mencapai sasaran Renstra 2015-2019 yakni 2,3 (Pemerintah Daerah DIY, 2018).

Kontrasepsi merupakan suatu upaya untuk mencegah bertemunya sel telur dengan sperma. Di Indonesia alat kontrasepsi dikelompokan menjadi 2 yaitu MKJP (Metode Kontasepsi Jangka Panjang) dan non MKJP. MKJP terdiri dari Intra Uterine Device (IUD), Metode Operasi Pria (MOP) atau vasektomi, Metode Operasi Wanita (MOW) atau tubektomi, dan implant. Sedangkan non MKJP terdiri dari kondom, pil, dan suntik (SDKI, 2017).

Tubektomi (Metode Operasi Wanita / MOW) termasuk dalam MKJP yang bersifat sukarela bagi seorang wanita bila tidak ingin hamil lagi. Hal ini dilakukan dengan cara mengikat atau memotong saluran tuba sehingga sperma tidak dapat bertemu dengan ovum. Kontrasepsi tubektomi terbukti paling efektif dengan memiliki angka kegagalan yang paling rendah dibandingkan dengan alat kontrasepsi lainnya (Pemerintah Daerah DIY, 2018).

Cakupan pengguna KB aktif di Indonesia tahun 2017 yaitu KB pil sebanyak $(17,24 \%)$, suntik (63.77\%), IUD (7,15\%), implant (6,99\%), tubektomi $(2,78 \%)$, kondom $(1,22 \%)$, dan vasektomi $(0,53 \%)$ (Kementrian RI, 2017). Penelitian ini dilakukan di Puskesmas Srandakan dikarenakan data cakupan KB Tubektomi tahun 2018 di kecamatan Srandakan adalah yang terendah di Kabupaten Bantul. Hasil studi pendahuluan yang telah dilakukan di Puskesmas Srandakan didapatkan hasil bahwa jumlah peserta KB aktif tahun 2018 sebanyak 258 akseptor, dengan metode kontrasepsi yang paling banyak digunakan adalah KB suntik dan IUD.

Beberapa Penelitian terdahulu banyak meneliti terkait faktor yang berhubungan dengan pemilihan kontrasepsi tubektomi khususnya variabel pengetahuan dan sikap. Namun penelitian ini memfokuskan pada faktor umur, pendidikan, pengetahuan dan paritas, selain itu penelitian tentang faktor-faktor yang berhubungan dengan pemilihan kontrasepsi tubektomi ini belum pernah dilakukan di wilayah kerja Puskesmas Srandakan. 


\section{METODE PENELITIAN}

Jenis penelitian ini dengan pendekatan Cross sectional. Populasi dalam penelitian ini adalah seluruh Wanita Usia Subur peserta KB aktif dengan jumlah sampel 72 responden. Teknik pengambilan sampel dengan Accidental Sampling. Penelitian ini menggunakan data primer dengan kuesioner pengetahuan tentang KB tubektomi dan lembar checklist karakteristik responden. Sebelumnya peneliti menentukan subjek penelitian yaitu wanita usia subur peserta KB aktif. Penelitian dilakukan secara mandiri oleh peneliti dengan mengunjungi lokasi penelitian sebanyak \pm 12 kali dan bertemu langsung dengan responden. Responden menandatangani informed consent sebagai bentuk persetujuan dan kesediaan untuk berpartisipasi dalam penelitian ini. Responden akan menjawab kuesioner yang telah dilakukan uji validitas dalam waktu 15-20 menit.

\section{HASIL PENELITIAN}

Tabel. 1

Distribusi Frekuensi Berdasarkan

Umur Wanita Usia Subur

\begin{tabular}{lccc}
\hline & Karakteristik Responden & Frekuensi $(f)$ & Persentase $(\%)$ \\
\hline \multirow{2}{*}{ Umur } & $\leq 30$ tahun & 28 & 38,9 \\
& $>30$ tahun & 44 & 61,1 \\
\hline Jumlah $(\mathrm{n})$ & & 72 & 100 \\
\hline
\end{tabular}

(Sumber : Data Primer 2019)

Berdasarkan tabel 1 dapat diketahui bahwa sebagian besar responden yaitu wanita usia subur berusia $>30$ tahun sebanyak 44 responden $(61,1 \%)$.

Tabel. 2

Distribusi Frekuensi Pendidikan

Wanita Usia Subur

\begin{tabular}{llcc}
\hline & Karakteristik Responden & Frekuensi $(f)$ & Persentase (\%) \\
\hline Pendidikan & Tidak Sekolah & 2 & 2,8 \\
& SD & 5 & 6,9 \\
& SMP & 15 & 20,8 \\
& SMA/SMK & 40 & 55,6 \\
& PT & 10 & 13,9 \\
\hline Jumlah (n) & & 72 & 100 \\
\hline (Sumber : Data Primer 2019) & &
\end{tabular}

Berdasarkan tabel 2 sebagian besar responden memiliki riwayat pendidikan terakhir SMA/SMK sebanyak 40 responden $(55,6 \%)$.

Tabel. 3

Distribusi Frekuensi Pengetahuan

Wanita Usia Subur

\begin{tabular}{llcc}
\hline \multicolumn{2}{c}{ Karakteristik Responden } & Frekuensi $(f)$ & Persentase (\%) \\
\hline Pengetahuan & Baik & 32 & 44,4 \\
& Cukup & 30 & 41,7 \\
& Kurang & 10 & 13,9 \\
\hline Jumlah (n) & & 72 & 100 \\
\hline
\end{tabular}

(Sumber : Data Primer 2019) 
Berdasarkan tabel 3 sebagian besar responden memiliki pengetahuan baik tentang alat kontrasepsi Tubektomi sebanyak 32 responden $(44,4 \%)$.

Tabel. 4

Distribusi Frekuensi Paritas

Wanita Usia Subur

\begin{tabular}{lccc}
\hline & Karakteristik Responden & Frekuensi $(f)$ & Persentase (\%) \\
\hline Paritas & Primipara (1 anak) & 20 & 27,8 \\
& Multipara (2-4 anak) & 52 & 72,2 \\
& Grandemultipara ( $\geq 5$ anak) & 0 & 0 \\
\hline Jumlah (n) & & 72 & 100
\end{tabular}

Berdasarkan tabel 4 sebagian besar wanita usia subur memiliki jumlah paritas dengan multipara ( $2-4$ anak) sebanyak 52 responden $(72,2 \%)$.

Tabel. 5

Hubungan Umur Wanita Usia Subur dengan Minat dalam Pemilihan Alat kontrasepsi Tubektomi

\begin{tabular}{|c|c|c|c|c|c|c|c|}
\hline \multirow{3}{*}{ Umur WUS } & \multicolumn{4}{|c|}{ Minat Pemilihan Alat Kontrasepsi } & \multirow{2}{*}{\multicolumn{2}{|c|}{ Jumlah }} & \multirow{3}{*}{ Korelasi (p) } \\
\hline & \multicolumn{2}{|c|}{ Berminat } & \multicolumn{2}{|c|}{ Tidak Bermina } & & & \\
\hline & $\mathrm{F}$ & $\%$ & $\mathrm{~F}$ & $\%$ & $\mathrm{~F}$ & $\%$ & \\
\hline$\leq 30$ Tahun & 6 & 35,3 & 22 & 78,6 & 28 & 100 & \\
\hline$>30$ Tahun & 11 & 25,0 & 33 & 75,0 & 44 & 100 & 0,732 \\
\hline Total & 17 & 23,6 & 55 & 76,4 & 72 & 100 & \\
\hline
\end{tabular}

Berdasarkan tabel 5 menunjukkan bahwa dari total 28 responden berusia $\leq 30$ Tahun, terdapat 6 responden $(35,3 \%)$ yang berminat menggunakan alat kontrasepsi Tubektomi, sedangkan 22 responden $(78,6 \%)$ tidak berminat menggunakan alat kontrasepsi Tubektomi. Dari total 44 responden berusia $>30$ tahun, terdapat 11 responden $(25,0 \%)$ yang berminat menggunakan alat kontrasepsi tubektomi, sedangkan 33 responden $(75,0 \%)$ tidak berminat menggunakan alat kontrasepsi tubektomi.

Hasil uji statistik didapatkan nilai $p=0,732>0,05$ yang berarti tidak ada hubungan antara umur dengan pemilihan kontrasepsi tubektomi pada wanita usia subur.

Tabel. 6

Hubungan Pendidikan Wanita Usia Subur dengan Minat dalam Pemilihan Alat kontrasepsi Tubektomi

\begin{tabular}{|c|c|c|c|c|c|c|c|}
\hline \multirow{3}{*}{$\begin{array}{l}\text { Pendidikan } \\
\text { WUS }\end{array}$} & \multicolumn{4}{|c|}{$\begin{array}{l}\text { Minat Pemilihan Alat Kontrasepsi } \\
\text { Tubektomi }\end{array}$} & \multirow{2}{*}{\multicolumn{2}{|c|}{ Jumlah }} & \multirow{3}{*}{$\begin{array}{c}\text { Korelasi } \\
\text { (p) }\end{array}$} \\
\hline & \multicolumn{2}{|c|}{ Berminat } & \multicolumn{2}{|c|}{ Tidak Berminat } & & & \\
\hline & $\mathrm{F}$ & $\%$ & $\mathrm{~F}$ & $\%$ & $\mathrm{~F}$ & $\%$ & \\
\hline Tidak Sekolah & 1 & 50,0 & 1 & 50,0 & 2 & 100 & \multirow{6}{*}{0,896} \\
\hline SD & 1 & 20,0 & 4 & 80,0 & 5 & 100 & \\
\hline SMP & 3 & 20,0 & 12 & 80,0 & 15 & 100 & \\
\hline SMA/SMK & 10 & 25,0 & 30 & 75,0 & 40 & 100 & \\
\hline PT & 2 & 20,0 & 8 & 80,0 & 10 & 100 & \\
\hline Total & 17 & 23,6 & 55 & 76,4 & 72 & 100 & \\
\hline
\end{tabular}


Berdasarkan tabel 6 dapat diketahui bahwa dari total 2 responden dengan status pendidikan tidak sekolah, terdapat 1 responden $(50,0 \%)$ yang berminat menggunakan alat kontrasepsi tubektomi. Dari total 5 responden dengan status pendidikan terakhir SD, terdapat 4 responden $(80,0 \%)$ tidak berminat menggunakan alat kontrasepsi tubektomi. Dari total 15 responden dengan status pendidikan terakhir SMP, terdapat 12 responden $(80,0 \%)$ tidak berminat menggunakan alat kontrasepsi tubektomi. Dari total 40 responden $(55,5 \%)$ dengan status pendidikan terakhir SMA/SMK, terdapat 30 responden $(75,0 \%)$ tidak berminat menggunakan alat kontrasepsi tubektomi. Dari total 10 responden dengan status pendidikan terakhir perguruan tinggi, terdapat 8 responden $(80,0 \%)$ tidak berminat untuk menggunakan alat kontrasepsi tubektomi.

Hasil uji statistik didapatkan nilai $p=0,896>0,05$ yang berarti tidak ada hubungan antara pendidikan dengan pemilihan kontrasepsi tubektomi pada wanita usia subur.

Tabel. 7

Hubungan Pengetahuan Wanita Usia Subur dengan Minat dalam Pemilihan Alat kontrasepsi Tubektomi

\begin{tabular}{|c|c|c|c|c|c|c|c|}
\hline \multirow{3}{*}{$\begin{array}{l}\text { Pengetahuan } \\
\text { WUS }\end{array}$} & \multicolumn{4}{|c|}{$\begin{array}{l}\text { Minat Pemilihan Alat kontrasepsi } \\
\text { Tubektomi }\end{array}$} & \multirow{2}{*}{\multicolumn{2}{|c|}{ Jumlah }} & \multirow{3}{*}{ Korelasi (p) } \\
\hline & \multicolumn{2}{|c|}{ Berminat } & \multicolumn{2}{|c|}{ Tidak Berminat } & & & \\
\hline & $\mathrm{F}$ & $\%$ & $\mathrm{~F}$ & $\%$ & $\mathrm{~F}$ & $\%$ & \\
\hline Baik & 7 & 21,9 & 25 & 78,1 & 32 & 100 & \multirow{4}{*}{0,886} \\
\hline Cukup & 8 & 26,7 & 22 & 73,3 & 30 & 100 & \\
\hline Kurang & 2 & 20,0 & 8 & 80,0 & 10 & 100 & \\
\hline Total & 17 & 23,6 & 55 & 76,4 & 72 & 100 & \\
\hline
\end{tabular}

Berdasarkan tabel 7 dapat diketahui bahwa dari total 32 responden dengan pengetahuan baik, terdapat 25 responden $(78,1 \%)$ yang tidak berminat untuk menggunakan alat kontrasepsi tubektomi. Dari 30 responden dengan pengetahuan cukup, terdapat 22 responden $(73,3 \%)$ yang tidak berminat untuk menggunakan alat kontrasepsi tubektomi. Dari 10 responden dengan pengetahuan kurang, terdapat 8 responden $(80,0 \%)$ tidak berminat untuk menggunakan alat kontrasepsi tubektomi.

Hasil uji statistik didapatkan nilai $p=0,086>0,05$ yang berarti tidak ada hubungan antara pengetahuan dan pemilihan kontrasepsi tubektomi pada wanita usia subur.

Tabel. 8

Hubungan Paritas Wanita Usia Subur dengan Minat dalam Pemilihan Alat kontrasepsi Tubektomi

\begin{tabular}{lccccccc}
\hline & \multicolumn{9}{c}{ MinatPemilihan Alat kontrasepsi Tubektomi } & \multirow{2}{*}{ Jumlah } & \multirow{2}{*}{ Korelasi (p) } \\
\cline { 2 - 6 } Paritas WUS & \multicolumn{2}{c}{ Berminat } & \multicolumn{2}{c}{ Tidak Berminat } & & & \\
\cline { 2 - 6 } & $\mathrm{F}$ & $\%$ & $\mathrm{~F}$ & $\%$ & $\mathrm{~F}$ & $\%$ & \\
\hline Primipara & 1 & 5,0 & 19 & 95,0 & 20 & 100 & \\
Multipara & 16 & 30,8 & 36 & 69,2 & 52 & 100 & \multirow{2}{*}{0,021} \\
Grandemultipara & 0 & 0 & 0 & 0 & 0 & 100 & \\
\hline Total & 17 & 23,6 & 55 & 76,4 & 72 & 100 & \\
\hline
\end{tabular}

(Sumber : Data Primer 2019) 
Berdasarkan tabel 8 diketahui bahwa dari total 20 responden dengan status paritas primipara, terdapat 19 responden $(95,0 \%)$ tidak berminat untuk menggunakan alat kontrasepsi tubektomi. Dari total 52 responden dengan status paritas multipara, terdapat 36 responden $(69,2 \%)$ yang tidak berminat untuk menggunakan alat kontrasepsi tubektomi.

Hasil uji statistik didapatkan nilai $p=0,021<0,05$ maka ada hubungan antara jumlah anak / paritas dengan pemilihan kontrasepsi tubektomi pada wanita usia subur.

\section{PEMBAHASAN}

\section{Hubungan Umur Wanita Usia Subur dengan Minat dalam Pemilihan Kontrasepsi Tubektomi}

Berdasarkan hasil penelitian, dapat diketahui bahwa sebagian besar responden adalah wanita usia subur berusia $>30$ tahun. Hasil uji statistik didapatkan nilai $p=$ 0,732 , tidak ada hubungan antara umur dengan pemilihan kontrasepsi tubektomi pada wanita usia subur. Sejalan dengan penelitian Rizkitama (2017) dengan hasil penelitian $p-$ value $=0,125$. Hal ini berarti tidak ada hubungan antara umur dengan partisipasi wanita dalam pemilihan kontrasepsi tubektomi.

Dari 44 responden berusia $>30$ tahun, terdapat 11 responden $(25.0 \%)$ yang berminat untuk menggunakan alat kontrasepsi tubektomi dan terdapat 33 responden (75.0\%) yang tidak berminat menggunakan alat kontrasepsi tubektomi. Hasil penelitian ini sejalan dengan penelitian Huda et al., (2016) dengan hasil penelitian $p-$ value = 0,282 yang berarti tidak ada hubungan antara umur dengan perilaku / minat penggunaan alat kontrasepsi. Responden yang memiliki perilaku kurang dalam menggunakan/ memilih alat kontrasepsi banyak ditemukan pada kelompok umur berisiko tinggi yaitu sebesar $(47,2 \%)$.

Dalam penelitian ini, wanita usia subur yang berumur $>30$ tahun diketahui sebanyak 33 responden (75\%) dan tidak berminat menggunakan kontrasepsi tubektomi. Secara teori dijelaskan bahwa wanita yang berusia lebih tua ( $>30$ tahun) diharapkan mulai melakukan pembatasan kehamilan bila sudah memiliki anak, karena pada usia tersebut beberapa organ reproduksi wanita mengalami perubahan, sehingga penggunaan alat kontrasepsi sangat diperlukan untuk mencegah kehamilan dengan risiko tinggi.

Penelitian ini tidak sejalan dengan penelitian yang dilakukan oleh Septiwiyarsi (2017) dengan hasil uji statistik $p=0,001$ yang berarti ada hubungan antara umur dengan pemilihan kontrasepsi tubektomi / MOW. Dalam penelitian tersebut dijelaskan bahwa adanya hubungan antara umur dengan pemilihan kontrasepsi. Metode operatif wanitta hal ini dikarenakan bahwa umur merupakan salah sau faktor yang mempengaruhi perilaku sesorang termasuk dalam pemakaian kontrasepsi, wanita yang berumur muda mempunyai peluang lebih kecil untuk memilih kontrasepsi mantap (MOW) dibandingkan dengan wanita yang berumur tua karena fungsi dari alat reproduksi sudah menurun sehingga bila hamil pada saat proses persalinan kemungkinan persalinan lama dan perdarahan selain itu, hal yang paling dikhawatirkan iyalah kualitas sel telur yang dihasilkan juga tidak baik.

Penelitian yang dilakukan Septiwiyarsi (2017) dengan hasil ada hubungan antara umur, paritas, dukungan suami, paparan informasi dan pengetahuan dengan pemilihan Kontrasepsi MOW di RS Muhammadiyah Palembang tahun 2016. 


\section{Hubungan Pendidikan Wanita Usia Subur dengan Minat dalam Pemilihan Kontrasepsi Tubektomi}

Berdasarkan hasil penelitian, dapat diketahui bahwa sebagian besar responden adalah memiliki tingkat pendidikan terakhir SMA/SMK. Hasil uji statistik didapatkan nilai $p=0,896$, nilai tersebut $>$ alpha $(0,05)$, yang berarti tidak ada hubungan antara pendidikan dengan pemilihan kontrasepsi tubektomi pada wanita usia subur di Wilayah Kerja Puskesmas Srandakan.

Dari 40 responden dengan tingkat pendidikan terakhir SMA/SMK, terdapat 10 responden $(25,0 \%)$ yang berminat, dan 30 responden $(75,0 \%)$ tidak berminat untuk menggunakan alat kontrasepsi Tubektomi. sejalan dengan penelitian yang dilakukan oleh Rahman et al. (2017) dengan hasil penelitian $p=0,604$ yang bermakna tidak ada hubungan antara pendidikan dengan penggunaan kontrasepsi MOW/tubektomi. Hal ini menunjukkan bahwa seseorang yang berpendidikan tinggi belum tentu akan memilih alat kontrasepsi tubektomi, melainkan memilih alat kontrasepsi jangka panjang lainnya. Keadaan ini dapat terjadi karena disertai faktor - faktor lain yang mempengaruhi pemikiran seseorang dalam memilih alat kontrasepsi yang akan digunakan. Perbedaan tingkat pendidikan akseptor $\mathrm{KB}$ terhadap pemilihan alat kontrasepsi yang akan digunakan, maka peran tenaga kesehatan diharapkan dapat memberikan konseling kepada pasangan usia subur sesuai pemahaman akseptor KB masing - masing.

Hasil penelitian yang dilakukan oleh Huda et al., (2016) dengan nilai $\mathrm{p}=0,009$ yang menunjukkan bahwa terdapat hubungan antara peran tenaga kesehatan dengan perilaku penggunaan alat kontrasepsi. Petugas kesehatan merupakan pihak yang mengambil peran dalam tahap akhir pemakaian alat kontrsaepsi calon akseptor KB, sebagai petugas kesehatan harus memberikan konseling secara jelas kepada akseptor $\mathrm{KB}$, menjelaskan alat kontrasepsi yang tepat dengan keadaan akseptor, serta tidak memaksa.

\section{Hubungan Pengetahuan Wanita Usia Subur dengan Minat dalam Pemilihan Alat Kontrasepsi Tubektomi}

Berdasarkan hasil penelitian, dapat diketahui bahwa sebagian besar responden memiliki tingkat pengetahuan baik. Hasil uji statistik didapatkan nilai $p=0,086$, yang berarti tidak ada hubungan antara pengetahuan dan pemilihan kontrasepsi tubektomi pada wanita usia subur.

Penelitian Septiwiyarsi (2017) menyatakan bahwa semakin banyak wanita usia subur terpapar informasi dari berbagai sumber yang diperoleh tentang alat kontrasepsi tubektomi, maka akseptor KB tersebut dapat memilih alat kontrasepsi yang sesuai kebutuhan. Tingkat pengetahuan tentang kontrasepsi, keamanan dan cara pemakaian termasuk pengetahuan tentang kemungkinan efek samping dan komplikasinya akan mempengaruhi mereka dalam memilih metode/ alat kontrasepsi yang akan digunakan termasuk keleluasaan atau kebebasan pilihan, kecocokan, pilihan efektif tidaknya, kenyamanan dan keamanan juga dalam memilih tempat pelayanan yang lebih sesuai dan lengkap karena wawasan sudah lebih baik. Pengetahuan responden ini dipengaruhi oleh beberapa faktor.

Penelitian Huda et al., (2016) menguatkan bahwa peran tenaga kesehatan sangat berpengaruh dalam pemilihan dan pengambilan keputusan akseptor $\mathrm{KB}$ untuk menggunakan alat kontrasepsi yang sesuai. Tenaga kesehatan dan para tenaga lain, merupakan pendorong atau penguat perilaku sehat pada masyarakat untuk untuk mencapai kesehatan, maka tenga kesehatan harus memperoleh pendidikan dan pelatihan 
khusus tentang kesehatan atau pendidikan kesehatan dan ilmu perilaku. Dalam hal ini, seorang tenaga kesehatan yang mempunyai pendidikan tinggi dan wawasan yang luas, maka akan mempengaruhi akseptor $\mathrm{KB}$ dalam mendapatkan informasi tentang alat kontrasepsi. Untuk mencapai tahap pengetahuan menjadi faham dan dapat mengaplikasikan secara tindakan, maka petugas kesehatan harus memberikan konseling disesuaikan dengan tingkat pendidikan akseptor KB sehingga mudah dipahami.

Penelitian Amalia (2016) menyatakan bahwa ada hubungan yang signifikan antara pengetahuan tentang KB menurut agama islam terhadap pemakaian alat kontrasepsi. Hal ini berarti sebagian besar akseptor $\mathrm{KB}$ yang tidak memilih menggunakan alat kontrasepsi jangka panjang dapat disebabkan karena faktor agama dan kepercayaan yang dianut.

\section{Hubungan Paritas Wanita Usia Subur dengan Minat dalam Pemilihan Alat Kontrasepsi Tubektomi}

Berdasarkan hasil penelitian, dapat diketahui bahwa sebagian besar responden memiliki jumlah paritas dengan multipara ( $2-4$ anak). Hasil uji statistik didapatkan nilai $p=0,021$, maka ada hubungan antara Jumlah anak / paritas dengan pemilihan kontrasepsi tubektomi pada wanita usia subur. Hasil penelitian yang sejalan dengan penelitian ini adalah penelitian oleh Bahu et al., (2019) dengan $p=0,004$ yang berarti ada hubungan antara peritas dengan minat penggunaan alat kontrasepsi tubektomi.

Dari 52 responden tersebut, terdapat 16 responden $(30,8 \%)$ yang berminat untuk menggunakan alat kontrasepsi tubektomi dan terdapat 36 responden $(69,2 \%)$ yang tidak berminat untuk menggunakan alat kontrasepsi tubektomi. Hal ini dikarenakan paritas dapat mempengaruhi seseorang dalam memilih alat kontrasepsi yang efektif dan mantap yang sesuai dengan kondisi dirinya untuk mencegah terjadinya kehamilan resiko tinggi yang dapat mengakibatkan bahaya hingga kematian ibu dan bayi. Sebaiknya semakin banyak paritas pasangan usia subur, maka semakin tinggi motivasi atau minat dalam menggunakan alat kontrasepsi terutama tubektomi.

Penelitian ini sejalan dengan penelitian yang dilakukan oleh Septiwiyarsi (2017) dengan hasil rata - rata jumlah anak responden yang memilih alat kontrasepsi tubektomi/ MOW yaitu wanita yang mempunyai 3 orang anak. Hasil uji statistic dengan nilai $p=0,001$ berarti ada hubungan antara jumlah anak / paritas yang mempengaruhi pemulihan kontrasepsi tubektomi / MOW. Demikian pula dengan penelitian Rizkitama (2017) dengan hasil uji statistik $p=0,026, \mathrm{OR}=3,623 ; 95 \%$ dan CI $1,166-11,257$ yang menyatakan bahwa faktor yang terbukti paling kuat hubungannya dengan partisipasi wanita dalam memilih alat kontrasepsi tubektomi adalah jumlah anak / paritas.

\section{SIMPULAN}

Karakteristik responden berdasarkan usia wanita subur sebagian besar responden berusia lebih dari 30 tahun. Mayoritas pendidikan wanita usia subur adalah SMA/SMK dan sebagian besar berpengetahuan baik. Sebagian besar wanita usia subur memiliki jumlah paritas multipara.

Faktor yang berhubungan dengan pemilihan kontrasepsi tubektomi pada wanita usia subur adalah jumlah paritas. Sedangakan tidak ada hubungan antara umur, pendidikan dan pengetahuan dengan pemilihan kontrasepsi tubektomi pada wanita usia subur. Semakin banyak jumlah anak, maka minat untuk mengehentikan kesuburan akan semakin besar, sehingga akseptor akan menggunakan kontrasepsi jangka panjang. 


\section{SARAN}

\section{Bagi Pelayanan}

Mampu memberikan konseling yang lebih komprehensif terhadap akseptor KB ketika ingin memilih alat kontrasepsi khususnya wanita usia subur yang telah berusia kurang produktif $>30$ tahun dan telah memiliki banyak anak. Dan dapat mempertimbangkan hasil penelitian ini sebagai kebijakan untuk memberikan pelayanan secara komprehensif, terutama KIE dan upaya promotif tentang alat kontrasepsi terutama kontrasepsi Tubektomi / MOW.

\section{Bagi Peneliti Selanjutnya}

Peneliti lanjutan untuk menganalisis secara multivariat, untuk mengetahui factorfaktor apakah yang paling berpengaruh dalam pemilihan kontrasepsi tubektomi pada wanita usia subur. Menambah variabel yang lain yang belum diteli misalnya pembiayaan, dukungan suami dan faktor agama.

\section{DAFTAR PUSTAKA}

Amalia, A. (2016). Pengetahuan tentang KB Menurut Agama Islam terhadap Pemakaian Alat Kontrasepsi di BPS Anik Susantu Amd Keb Dusun Jatirejo Desa Topeng Kecamatan Tikung Kabupaten Lamongan. Surya, 8(1), 32-39

Bahu, R., Hasania, E., \& Hilamuhu, F. (2019). Hubungan Paritas dan Dukungan Suami dengan Rendahnya Minat Penggunaan Alat Kontrasepsi Metode Tubektomi di Puskesmas Tibawa. Akademika: Jurnal Ilmiah Media Publikasi Ilmu Pengetahuan dan Teknologi, 8(1). https://doi.org/10.31314/akademika.v8i1.299

Dyah, P. E., \& Sariyati, S. (2016). Agama dengan Keikutsertaan Keluarga Berencana (KB) dan Pemilihan Jenis Alat Kontrasepsi pada Pasangan Usia Subur (PUS) di Desa Argomulyo Sedayu Bantul Yogyakarta. Jurnal Ners Dan Kebidanan Indonesia, 3(1), 1. https://doi.org/10.21927/jnki.2015.3

Huda, A., Widagdo, L., \& Widjanarko, B. (2016). Faktor-Faktor yang Berhubungan dengan Perilaku Penggunaan Alat Kontrasepsi pada Wanita Usia Subur di Puskesmas Jombang-Kota Tangerang Selatan. Jurnal Kesehatan Masyarakat (EJournal), 4(1), 461-469

Indraswari, R. R., \& Yuhan, R. J. (2017). Faktor-Faktor yang Memengaruhi Penundaan Kelahiran Anak Pertama di Wilayah Perdesaan Indonesia: Analisis Data SDKI 2012. Jurnal Kependudukan Indonesia, 12(1), 1. https://doi.org/10.14203/jki.v12i1.274

Kementrian RI. (2017). Profil Kesehatan Indonesia Tahun 2017. Profil Kesehatan Indonesia Tahun 2017

Pemerintah Daerah DIY. (2018). Angka Kelahiran Total DIY di Bawah Nasional Berita | Portal Pemda DIY

Rahman, Z., Kunoli, F. J., \& Amalinda, F. (2017). The Factors Related to the Application of Contraception Method of Women Operation (Mow). Promotif: $\begin{array}{llll}\text { Jurnal Kesehatan } & \text { Masyarakat, } & 7(2), & \end{array}$ https://doi.org/10.31934/promotif.v7i2.89

Rizkitama, A. A. (2017). Beberapa Faktor yang Berhubungan dengan Partisipasi Wanita dalam Pemilihan Tubektomi pada Peserta MKJP di Kecamatan Bumiayu Kabupaten Brebes. Universitas Diponegoro Semarang

SDKI. (2017). Survey Demografi dan Kesehatan Indonesia. In Survei Demografi dan Kesehatan Indonesia. https://doi.org/0910383107 [pii]\r10.1073/pnas.0910383107 
Septiwiyarsi, S. (2017). Analisis Faktor yang Mempengaruhi Pemilihan Kontrasepsi Metode Operatif Wanita (MOW) di Rumah Sakit Muhammadiyah Palembang Tahun 2016. Scientia Journal Stikes Prima Jambi,6(2)

Siregar, G. G. (2018). Analisa Faktor Dominan yang Mempengaruhi Wanita Pasangan Usia Subur terhadap Penggunaan Metode Kontrasepsi Tubektomi di Desa Sidomulyo Kabupaten Deli Serdang Tahun 2018. Jurnal Penelitian Kebidanan \& Kespro, 1(1), 13-17 